\title{
Influence of edaphic factors on the structure and distribution of plant species in and around Mekeiman Marsh Wetland, Northeast of Algeria
}

\author{
MOUNDJI TOUARFIA ${ }^{1,2, \boldsymbol{v}}$, NOUREDDINE BOUALI ${ }^{3}$, ABDELKADER DJOUAMAA ${ }^{1,2}$, \\ MOHAMED CHERIF MAAZI ${ }^{1,2}$, MOUSSA HOUHAMDI ${ }^{4}$ \\ ${ }^{1}$ Department of Biology, Faculty of Sciences and Nature, University Mohamed Cherif Messaadia. Souk-Ahras, 41000, Algeria \\ ${ }^{2}$ Laboratory of Terrestrial and Aquatic Ecosystem, Faculty of Sciences and Nature, University Mohamed Cherif Messaadia. Souk-Ahras, 41000 , Algeria. \\ "email: biomoundji@yahoo.fr \\ ${ }^{3}$ Department of Biology, Faculty of Sciences and Nature, University Echahid Hamma Lakhdar. Oued-Souf, 39000, Algeria \\ ${ }^{4}$ Laboratory of LBEE, Faculty SNV-STU, University 8 May 1945 Guelma. BP 40124000 Guelma, Algeria
}

Manuscript received: 16 February 2021. Revision accepted: 18 May 2021.

\begin{abstract}
Touarfia M, Bouali N, Djouamaa Ak, Maazi MC, Houhamdi M. 2021. Influence of edaphic factors on the structure and distribution of plant species in and around Mekeiman Marsh Wetland, Northeast of Algeria. Biodiversitas 22: $3219-3228$. Understanding the environmental factors that influence plant species composition and distribution is essential for successful management of biodiversity. Hence, the purpose of the present study was to assess plant species composition and distribution in a freshwater wetland Mekeiman Marsh, Northeastern Algeria and to analyze the influence of environmental factors on local plant species. To explore the distribution of plant species in this Marsh and analyze their associations with edaphic soil factors, the mapping and types of plant species in this area were analyzed by MapInfo and principal component analysis (PCA) ordination. For this purpose, four stations were chosen according to a stratified sampling method and phytosociological surveys were carried out in 12 plots, which were sampled using the Braun- Blanquet method. Multivariate analyses were used to determine the relationship between plant species distribution and edaphic factors. The $R$ i386 (version 4.0.3) software was used for data analysis. We have identified 48 plant species belonging to 21 families. Results of biological types in the study area revealed the dominance of hemicryptophytes and therophytes, which indicates the presence of therophytization in this Marsh. Spatial distribution maps showed that plant species were divided into two categories viz. sparse and scattered plants according to the humidity gradient. The most important edaphic factors associated with plant species in Mekeiman Marsh were Sodium, Phosphorus, active limestone, Magnesium, clay, organic matter, C/N and Azot. By combining mapping and influence of edaphic factors on the structure and distribution of plant species in this wetland, it was known that the plant assemblages of this Marsh make disproportionately important contributions to wetland-level diversity.
\end{abstract}

Keywords: Biological types, environmental factors, phytosociological surveys, species composition, therophytization

\section{INTRODUCTION}

The structure and diversity of plant species in wetland ecosystem are determined by the distribution of several environmental factors, which act at different spatial scales. Plant species distribution is influenced by several processes that include biotic and abiotic interactions (Wang et al. 2018; Chen et al. 2019). Among the abiotic factors, soil type plays a major role in the heterogeneity of habitats and differentiation of the vegetation (Demenois et al. 2018; Chang and Turner 2019; Zhang et al. 2019). This ultimately results in changes in the structure of plant species community and on their diversity. Among the edaphic factors, the nutrient content in the soil may affect parameters thus consequently influence the structure of plant species communities (Maren and Sharma 2018; Eghdami et al. 2019).

Plant species diversity in wetland ecosystems has been described by several studies (O'Connell et al. 2012; Williams and Ahn 2015; Jager et al. 2015) these works proved that soil conditions to be the main environmental factor affecting wetland plant species. According to the study in Oued Charef dam ecosystem, Northeastern Algeria plant species are positively related to soil factors (Moualki and Boukrouma 2021). Some researchers observed a positive relationship between community biodiversity and edaphic gradients ( $\mathrm{Gu}$ et al. 2019; Silva et al. 2018). However, Violle et al. (2011) and Wu et al. (2013) also observed a negative relationship between plant species and edaphic gradients. Overall, the impact of soil factors on the wetland plant species is complex as it involves a multitude of factors whose thorough study is important and useful for understanding of the wetland plant-edaphic relationships.

Mekeiman wetland is the largest freshwater Marsh lake in Northeastern Algeria, with dramatic annual and seasonal hydrological fluctuation. These fluctuation changes lead to abundant wetland vegetation in this area. However, little has been reported on the relationships between soil properties and vegetation distribution patterns in Algeria.

The main purposes of this study were to determine the zonation pattern of plant species communities in relation to edaphic factors in Mekeiman Marsh, Northeast of Algeria as baseline data to get a better understanding of the potentially crucial soil factors on vegetation in Mekeiman Marsh wetland for a better conservation and monitoring strategies. 


\section{MATERIALS AND METHODS}

\section{Study area}

The study was conducted in Mekeiman Marsh wetland $\left(36^{\circ} 4^{\prime} 32.79^{\prime \prime} \mathrm{N}, 8^{\circ} 15^{\prime} 43.97 " \mathrm{E}\right)$, a semi-arid area, located in the Municipality of Sidi Fredj, District of Merahna, Province of Souk Ahras (Northeastern Algeria) (Figure 1). (Guesmi 2004).

\section{Data collection}

\section{Vegetation sampling procedures}

This study was conducted between September 2019 to October 2020, at each output, we collected several samples of plant species for identification, and voucher specimens have been submitted at the 'Flora of Morocco and Algeria in the N.C.W. Beadle Herbarium'. The position of plant species on the ground (geographical coordinates and altitude) were derived from GPS (GARMIN Oregon ${ }^{\mathrm{TM}}$ 450 ), the identification of species was made in consultation with literature such as the flora of Algeria (Quezel and Santa 1962), Wild plants (Jerôme 2011), edible and poisonous wild plants (Couplan and Styner 2013), and the flora of the Sahara (Ozenda 1986).

The study of plant species cover requires analysis of the plant structure through floristic surveys. For the sampling technique, we have chosen subjective sampling because the latter is considered by many authors as the simplest and most intuitive to characterize plant groups (Meddour 1994; Touarfia 2012). When performing a plant species survey, two important criteria are considered: homogeneity and geomorphologic homogeneity (Gillet 2000). All the plant species in the phytosociological surveys are accompanied by a sociability coefficient (Gillet 2000) (Figure 2) and the biological type (Raunkiær et al. 1934). To overcome the limitations of counting species, we have used the BraunBlanquet cover-abundance scale (Braun-Blanquet 1932, 1964), as shown in Table 1, to estimate species importance in studies of herbaceous and shrubby vegetation. Only the index designating the appropriate cover range was recorded in the field.

Table 1. Braun-Blanquet cover-abundance scale

\begin{tabular}{ll}
\hline $\begin{array}{l}\text { Braun- } \\
\text { Blanquet scale }\end{array}$ & Range of cover $(\%)$ \\
\hline 5 & $75-100$ \\
4 & $50-75$ \\
3 & $25-50$ \\
2 & $5-25$ \\
1 & $<5 ;$ numerous individuals \\
+ & $<5 ;$ few individuals \\
$\mathrm{r}$ & $<5 ;$ less than 1\% plot cover, 3-5 individuals \\
$\mathrm{i}$ & i: Species represented by a unique individual \\
\hline
\end{tabular}

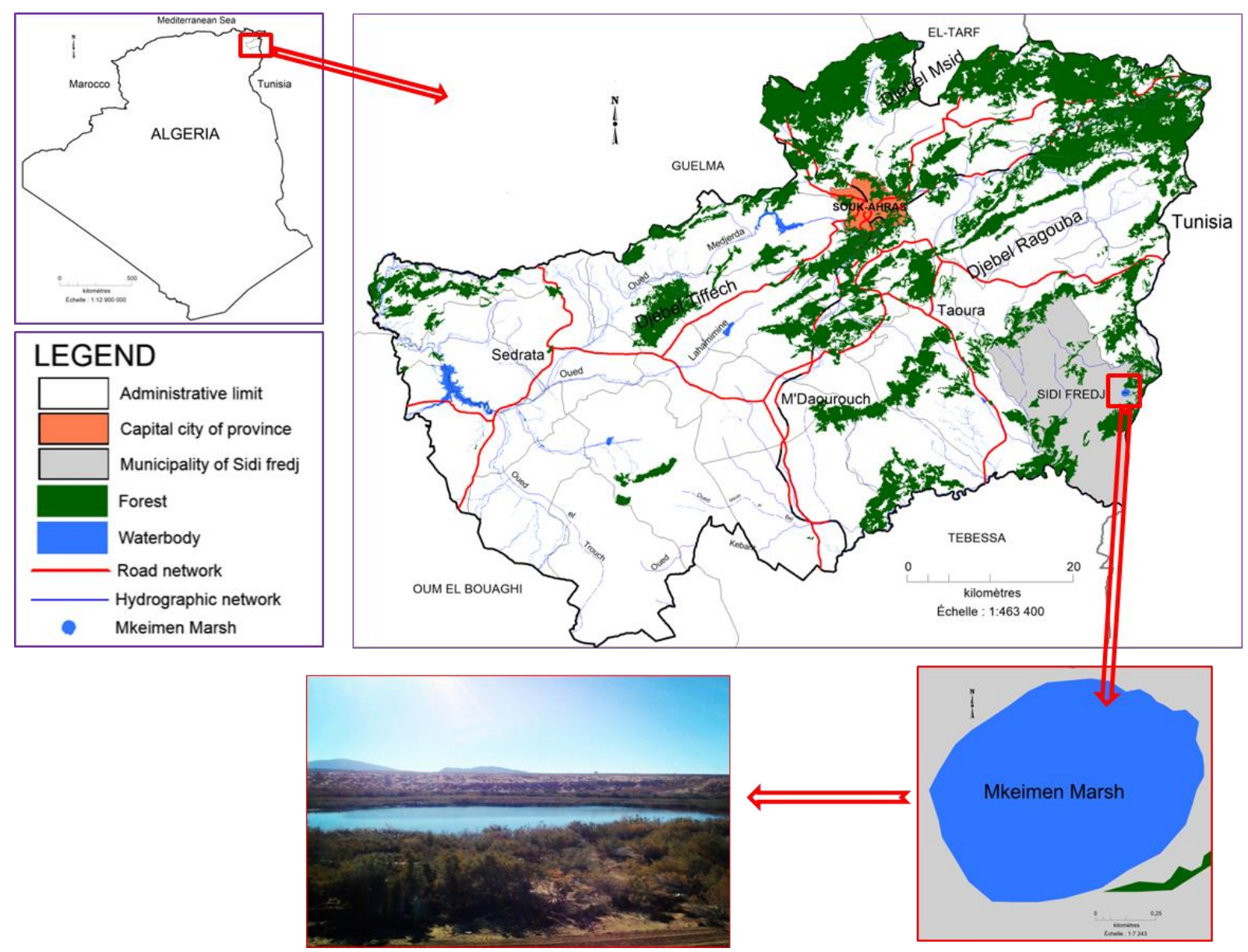

Figure 1. Site location map in Mekeiman Marsh, Souk Ahras, Northeast of Algeria 


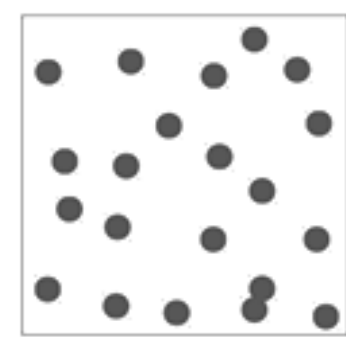

1

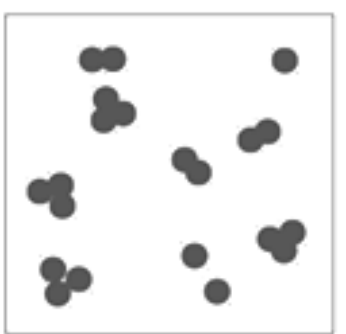

2

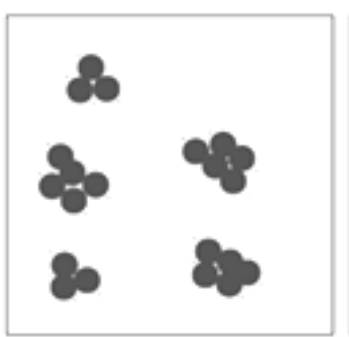

3

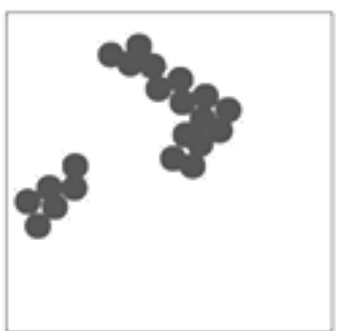

4

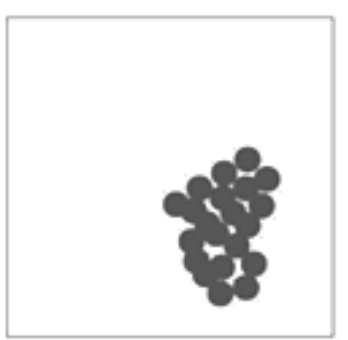

5

Figure 2. Schematic representation of sociability coefficient (Gillet 2000). Note: 1: elements distributed sporadically or very diluted; 2 : elements forming open stands, very fragmented in small spots with often diffuse outlines; 3: elements forming closed stands but fragmented into small islands; 4: elements forming several closed stands, often anastomosing, with clear outlines; 5: elements forming a single stand

\section{Mapping of vegetation distribution}

The mapping of spatial distribution and arrangement of plant groups were made using MapInfo version 12.0, mapping software, and GIS in the study area. The plant species groups were labeled with particular symbols. Following Long (1974) and Ozenda (1986), the present study incorporates large-scale mapping which is the most appropriate and the most suitable for the representation of the plant species cover and constitutes the most elaborate form of expression for the precise definition of the plant species.

\section{Soil analysis}

Soil samples were collected from 12 plots (representing three plots each from four stations) so that they were homogeneous and representative of the entire Marsh. Soil profiles were dug using an auger to depths varying: $0 \mathrm{~cm}$ to $20 \mathrm{~cm} ; 20 \mathrm{~cm}$ to $40 \mathrm{~cm}$ and $40 \mathrm{~cm}$ to $60 \mathrm{~cm}$ (Soltner 2005). The choice of this technique was two-fold; on one hand, the characterization of the soil at the four stations in question (physicochemical pedological analyzes), and on the other hand, the observation of the influence of soil characteristics on the distribution (Chenchouni 2007), and therefore the recovery of species plants that are found near Marsh of Mekeiman. The measurements of salinity, electrical conductivity and ${ }_{\mathrm{p}} \mathrm{H}\left(\mathrm{H}_{2} \mathrm{O}\right)$ were carried out in situ (at the time of sampling) using a multi-parameter (Consort- c 5010), all other analyzes: the $\mathrm{C} / \mathrm{N}$, Carbonate, Active Limestone, Organic Matter, Total Nitrogen, Phosphorus, Potassium, Magnesium, Calcium, Sodium and particle size determination were performed at Laboratory of Biology, Water and Environment (LBEE), University 8 May 1945 Guelma. Algeria.

\section{Data analysis}

For data analysis, the R 4.0.3 ( $\mathrm{R}$ core Team 2016) program was used to calculate the arithmetic average, standard deviation, minimum and maximum value for each of the studied features, for each plant species and edaphic factors. The principal component analysis (PCA) was used to investigate the correlation between edaphic factors and plant species in Mekeiman Marsh. PCA was carried out in the "Facto Miner" package for R program. PCA is the technique of ordination which builds the theoretical variable that minimizes the total residual number of squares to edaphic and species data after fitting straight lines.

\section{RESULTS AND DISCUSSION}

In total, we recorded 48 plant species belonging to 21 families from four stations of Mekeiman Marsh (Table 2). The most represented families were: Compositae (11 species) and Poaceae (8 species), Lamiaceae and Plantaginaceae were represented with 3 species each, Amaranthaceae, Boraginaceae and Brassicaceae were represented by 2 species each, while rest families were represented by unitary species. The abundance of the various species related to their biological type according is as follows: hemicryptophytes > therophytes > chamaephytes > geophytes > microphanerophytes > nanophanerophytes. (Table 2).

A summary of abundance dominance and sociability of species importance in the Mekeiman Marsh wetland (Table 3) serves as an example for application of cover data. Parameters shown here for each of the 48 species present are: (i) abundance dominance, (ii) sociability . Dominance (based on cover) of species: Bolboschoenus maritimus (L.) Palla, Scirpoides holoschoenus (L.), Soják, Juncus acutus (L.), Phragmites australis (Cav.) Trin. ex Steud, Tamarix canariensis Willd. and Typha angustifolia (L.) in the Marsh is clearly shown. Because absolute data, shown here as average cover, are based on a percentage, uniform comparison can be made among as well as within development sites.

The vegetation map shows that the plant species in Mekeiman Marsh are divided into two main categories according to the humidity gradient: The first category includes species with a sociability coefficient of 4 to 5 (Figure 3). These are hygrophilic plants (very humid) and hygrocline plants (fairly humid) where the groups of plants settle around on the outskirts of the Marsh and inside the wetland, which include Phragmites australis, Typha angustifolia, Juncus acutus, Bolboschoenus maritimus, Tamarix canariensis and Scirpoides holoschoenus. These groups are characterized by high density and large range 
expansion with $50 \%$ to $75 \%$ coverage per survey. The rest of the floristic procession represents the second category represented by scattered and dispersed plants with sociability coefficient of 1 to 2 and a low recovery rate of $1 \%$ to $10 \%$ indicating development of these plants in semiarid steppe environments.

The Edaphic feature of Mekeiman Marsh showed mean value of Sand $41.00 \pm 3.65$, Silt $27.50 \pm 3$, clay $31.50 \pm 5$, C/N $5.95 \pm 0.63(\%)$ respectively and conductivity $(\mathrm{mS} / \mathrm{cm})$
$2.99 \pm 1.22$. The soil of this wetland was neutral having the man value of $\mathrm{pH} 7.94 \pm 0.129$. While in case of the soil nutrients showed the value of carbonates $9.98 \pm 1.66$, active limestone $4.91 \pm 2.40$, organic matter $0.94 \pm 0.19$, nitrogen $0.30 \pm 0.45(\%)$ respectively, phosphorus $0.01 \pm 0.01$, potassium $0.53 \pm 0.10$, magnesium $5.32 \pm 0.27$, calcium $43.29 \pm 1.06$ and sodium $3.55 \pm 0.93 \quad(\mathrm{meq} / 100 \mathrm{~g})$ respectively (Table 4).

Table 2. Inventoried plant species with their abundance in the four stations in Mekeiman Marsh wetland, Northeastern Algeria

\begin{tabular}{|c|c|c|c|c|c|c|c|}
\hline \multirow{2}{*}{ Family } & \multirow{2}{*}{ Species } & \multirow{2}{*}{ Abbreviation } & \multirow{2}{*}{ Biological type } & \multicolumn{4}{|c|}{ Station } \\
\hline & & & & 1 & 2 & 3 & 4 \\
\hline Amaranthaceae & Atriplex halimus L. & A.tha & Nanophanerophytes & 1 & 0 & 0 & 1 \\
\hline \multirow[t]{12}{*}{ Compositae } & Chenopodium polyspermum $\mathrm{L}$. & C.hpo & Therophytes & 1 & 4 & 7 & 2 \\
\hline & Andryala integrifolia $\mathrm{L}$. & A.nin & Therophytes & 3 & 6 & 2 & 0 \\
\hline & Artemisia herba-alba Asso. & A.rhe & Chamephytes & 19 & 10 & 14 & 15 \\
\hline & Calendula arvensis (Vaill.) L. & C.aar & Therophytes & 5 & 10 & 3 & 2 \\
\hline & Galactites tomentosus Moench & G.ato & Hemicryptophytes & 0 & 1 & 0 & 1 \\
\hline & Matricaria chamomilla $\mathrm{L}$. & M.ach & Therophytes & 4 & 0 & 5 & 2 \\
\hline & Pallenis spinosa (L.) Cass. & P.asp & Hemicryptophytes & 0 & 2 & 3 & 1 \\
\hline & Scolymus hispanicus L. & S.chi & Hemicryptophytes & 1 & 0 & 0 & 0 \\
\hline & Senecio vulgaris $\mathrm{L}$. & S.evu & Therophytes & 0 & 0 & 0 & 2 \\
\hline & Silybum marianum (L.) Gaertn. & S.ima & Hemicryptophytes & 0 & 1 & 1 & 2 \\
\hline & Sonchus asper (L.) Hill & S.oas & Therophytes & 0 & 1 & 1 & 0 \\
\hline & Taraxacum campylodes G.E.Haglund & T.aca & Hemicryptophytes & 2 & 5 & 3 & 3 \\
\hline \multirow[t]{2}{*}{ Boraginaceae } & Borago officinalis L. & B.oof & Therophytes & 0 & 2 & 0 & 1 \\
\hline & Echium creticum $\mathrm{L}$. & E.ccr & Hemicryptophytes & 0 & 2 & 3 & 2 \\
\hline \multirow{2}{*}{ Brassicaceae } & Raphanus raphanistrum $\mathrm{L}$. & R.ara & Therophytes & 0 & 7 & 6 & 7 \\
\hline & Sinapis arvensis L. & S.iar & Therophytes & 0 & 4 & 6 & 3 \\
\hline \multirow{2}{*}{ Cistaceae } & Helianthemum apenninum (L.) Mill. & H.eap & Chamephytes & 5 & 0 & 0 & 0 \\
\hline & Helianthemum nummularium (L.) Mill. & Н.епи & Chamephytes & 7 & 0 & 0 & 0 \\
\hline Cupressaceae & Juniperus communis L. & J.uco & Microphanerophytes & 0 & 1 & 1 & 2 \\
\hline \multirow{2}{*}{ Cyperaceae } & Bolboschoenus maritimus (L.) Palla & B.oma & Geophytes & 14 & 16 & 18 & 13 \\
\hline & Scirpoides holoschoenus (L.) Soják & S.cho & Hemicryptophytes & 6 & 2 & 3 & 1 \\
\hline \multirow[t]{2}{*}{ Fabaceae } & Lathyrus L. & L.ath & Therophytes & 0 & 5 & 10 & 7 \\
\hline & Vicia sativa $\mathrm{L}$. & V.isa & Therophytes & 0 & 6 & 8 & 11 \\
\hline Juncaceae & Juncus acutus L. & J.uac & Hemicryptophytes & 35 & 23 & 19 & 13 \\
\hline \multirow[t]{3}{*}{ Lamiaceae } & Marrubium vulgare L. & M.avu & Hemicryptophytes & 2 & 3 & 0 & 0 \\
\hline & Rosmarinus officinalis L. & R.oof & Chamephytes & 43 & 25 & 27 & 43 \\
\hline & Thymus vulgaris L. & T.hvu & Chamephytes & 9 & 4 & 5 & 5 \\
\hline Malvaceae & Malva sylvestris L. & M.asy & Hemicryptophytes & 0 & 0 & 1 & 2 \\
\hline Nitrariaceae & Peganum harmala $\mathrm{L}$. & P.eha & Chamephytes & 16 & 24 & 37 & 64 \\
\hline Papaveraceae & Papaver rhoeas L. & P.arh & Therophytes & 0 & 3 & 1 & 0 \\
\hline \multirow[t]{3}{*}{ Plantaginaceae } & Globularia alypum L. & G.lal & Chamephytes & 9 & 3 & 10 & 19 \\
\hline & Plantago lanceolata $\mathrm{L}$. & P.lla & Hemicryptophytes & 0 & 1 & 3 & 0 \\
\hline & Plantago major L. & P.lma & Hemicryptophytes & 7 & 14 & 12 & 22 \\
\hline \multirow{8}{*}{ Poaceae } & Aira elegantissima Schur. & A.iel & Therophytes & 0 & 10 & 0 & 0 \\
\hline & Ampelodesmos mauritanicus (Poir.) & A.mma & Hemicryptophytes & 0 & 2 & 4 & 0 \\
\hline & $\begin{array}{l}\text { Arrhenatherum elatius (L.) P.Beauv. ex } \\
\text { J.Presl \& C.Presl. }\end{array}$ & A.rel & Hemicryptophytes & 0 & 3 & 0 & 0 \\
\hline & Hordeum murinum L. & Н.оти & Therophytes & 12 & 25 & 17 & 21 \\
\hline & Stipa tenacissima $\mathrm{L}$. & S.tte & Hemicryptophytes & 0 & 0 & 1 & 2 \\
\hline & Phleum pratense $\mathrm{L}$. & P.hpr & Hemicryptophytes & 0 & 3 & 4 & 0 \\
\hline & Phragmites australis (Cav.) Trin. ex Steud. & P.hau & Geophytes & 61 & 51 & 48 & 59 \\
\hline & Vulpia myuros (L.) C.C.Gmel. & V.umy & Therophytes & 21 & 31 & 18 & 37 \\
\hline Primulaceae & Anagallis monelli $\mathrm{L}$. & L.ymo & Hemicryptophytes & 3 & 8 & 4 & 7 \\
\hline Ranunculaceae & Ranunculus arvensis L. & R.aar & Therophytes & 2 & 1 & 5 & 0 \\
\hline Resedaceae & Reseda alba $\mathrm{L}$. & R.eal & Hemicryptophytes & 1 & 5 & 2 & 0 \\
\hline Rhamnaceae & Ziziphus lotus (L.) Lam. & Z.ilo & Chamephytes & 4 & 3 & 10 & 10 \\
\hline Tamaricaceae & Tamarix canariensis Willd. & T.aca & Microphanerophytes & 6 & 4 & 3 & 7 \\
\hline Typhaceae & Typha angustifolia $\mathrm{L}$. & T.yan & Geophytes & 46 & 49 & 39 & 62 \\
\hline
\end{tabular}


Table 3. Summary of plant species with their abundance dominance according to Braun-Blanquet cover scale and sociability in Mekeiman Marsh wetland, Northeastern Algeria

\begin{tabular}{|c|c|c|c|c|}
\hline Family & Species & Abbreviation & $\begin{array}{l}\text { Abundance- } \\
\text { dominance }\end{array}$ & Sociability \\
\hline Amaranthaceae & Atriplex halimus L. & A.tha & $\mathrm{r}$ & 1 \\
\hline \multirow[t]{12}{*}{ Compositae } & Chenopodium polyspermum $\mathrm{L}$. & C.hpo & + & 1 \\
\hline & Andryala integrifolia $\mathrm{L}$. & A.nin & + & 1 \\
\hline & Artemisia herba-alba Asso. & A.rhe & 1 & 1 \\
\hline & Calendula arvensis (Vaill.) L. & C.aar & 1 & 1 \\
\hline & Galactites tomentosus Moench & G.ato & $\mathrm{r}$ & 1 \\
\hline & Matricaria chamomilla L. & M.ach & + & 1 \\
\hline & Pallenis spinosa (L.) Cass. & P.asp & + & 1 \\
\hline & Scolymus hispanicus L. & S.chi & $\mathrm{i}$ & 1 \\
\hline & Senecio vulgaris $\mathrm{L}$. & S.evu & $\mathrm{r}$ & 1 \\
\hline & Silybum marianum (L.) Gaertn. & S.ima & + & 1 \\
\hline & Sonchus asper (L.) Hill & S.oas & $\mathrm{r}$ & 1 \\
\hline & Taraxacum campylodes G.E.Haglund & T.aca & + & 1 \\
\hline \multirow[t]{2}{*}{ Boraginaceae } & Borago officinalis L. & B.oof & + & 1 \\
\hline & Echium creticum $\mathrm{L}$. & E.ccr & + & 1 \\
\hline \multirow[t]{2}{*}{ Brassicaceae } & Raphanus raphanistrum $\mathrm{L}$. & R.ara & + & 1 \\
\hline & Sinapis arvensis $\mathrm{L}$. & S.iar & + & 1 \\
\hline \multirow{2}{*}{ Cistaceae } & Helianthemum apenninum (L.) Mill. & H.eap & + & 1 \\
\hline & Helianthemum nummularium (L.) Mill. & Н.епи & + & 1 \\
\hline Cupressaceae & Juniperus communis L. & J.uco & + & 1 \\
\hline \multirow[t]{2}{*}{ Cyperaceae } & Bolboschoenus maritimus (L.) Palla & B.oma & 3 & 5 \\
\hline & Scirpoides holoschoenus (L.) Soják & S.cho & 1 & 5 \\
\hline \multirow[t]{2}{*}{ Fabaceae } & Lathyrus L. & L.ath & 1 & 1 \\
\hline & Vicia sativa $\mathrm{L}$. & V.isa & + & 1 \\
\hline Juncaceae & Juncus acutus L. & J.uac & 4 & 5 \\
\hline \multirow[t]{3}{*}{ Lamiaceae } & Marrubium vulgare $\mathrm{L}$. & M.avu & + & 1 \\
\hline & Rosmarinus officinalis $\mathrm{L}$. & R.oof & 3 & 1 \\
\hline & Thymus vulgaris L. & T.hvu & 1 & 1 \\
\hline Malvaceae & Malva sylvestris $\mathrm{L}$. & M.asy & + & 1 \\
\hline Nitrariaceae & Peganum harmala $\mathrm{L}$. & P.eha & 3 & 1 \\
\hline Papaveraceae & Papaver rhoeas L. & P.arh & + & 1 \\
\hline \multirow[t]{3}{*}{ Plantaginaceae } & Globularia alypum L. & G.lal & 1 & \\
\hline & Plantago lanceolata $\mathrm{L}$. & P.lla & + & 1 \\
\hline & Plantago major L. & P.lma & 1 & 1 \\
\hline \multirow[t]{8}{*}{ Poaceae } & Aira elegantissima Schur. & A.iel & + & 1 \\
\hline & Ampelodesmos mauritanicus (Poir.) T.Durand \& Schinz. & A.mma & + & 1 \\
\hline & Arrhenatherum elatius (L.) P.Beauv. ex J.Presl \& C.Presl. & A.rel & 2 & 1 \\
\hline & Hordeum murinum L. & Н.оти & + & 1 \\
\hline & Stipa tenacissima $\mathrm{L}$. & S.tte & + & 1 \\
\hline & Phleum pratense $\mathrm{L}$. & P.hpr & + & 1 \\
\hline & Phragmites australis (Cav.) Trin. ex Steud. & P.hau & 5 & 5 \\
\hline & Vulpia myuros (L.) C.C.Gmel. & V.umy & 2 & 1 \\
\hline Primulaceae & Anagallis monelli $\mathrm{L}$. & L.ymo & 1 & 1 \\
\hline Ranunculaceae & Ranunculus arvensis $\mathrm{L}$. & R.aar & + & 1 \\
\hline Resedaceae & Reseda alba $\mathrm{L}$. & R.eal & + & 1 \\
\hline Rhamnaceae & Ziziphus lotus (L.) Lam. & Z.ilo & 1 & 1 \\
\hline Tamaricaceae & Tamarix canariensis Willd. & T.aca & 4 & 5 \\
\hline Typhaceae & Typha angustifolia $\mathrm{L}$. & T.yan & 5 & 5 \\
\hline
\end{tabular}

Note: Abundance-dominance coefficient: 5: 75-100\%; 4: 50-75\%; 3: 25-50\%; 2: 5-25\%; 1: <5: numerous individuels; +:<5: few individuels; r: <5: less than 1\% plot cover, 3-5 individuels; i: Species represented by a unique individual. Sociability coefficient: 1 : elements distributed sporadically or very diluted; 2: elements forming open stands, very fragmented in small spots with often diffuse outlines; 3: elements forming closed stands but fragmented into small islands; 4: elements forming several closed stands, often anastomosing, with clear outlines; 5: elements forming a single stand

The PCA conducted on the edaphic factors and species variables summarized them into two independent factors (PC1 and PC2) accounting together for $77.02 \%$ of the variance of the original data set. The first ordination axis (PC1, 43.13\%) showed a positive correlation with Organic matter, Nitrogen, Sodium, Clay and a negative correlation with $\mathrm{pH}$, Carbonates, Active limestone, Potassium, Calcium and Silt which favored species like A.iel, A.mma, A.nin, A.rel B.oma, B.oof, C.aar, E.ccr, H.omu, L.ath, C.hpo,, L.ymo, P.asp, P.arh, P.hpr, P.lla, R.ara, R.eal, 
S.iar, S.oas and T.aca in station (2), (3) and (4) (Figure 3), (Table 2). In addition, the second component (PC2, $33.89 \%$ ) is characterized by a positive correlation with $\mathrm{C} / \mathrm{N}$, Active limestone, Phosphorus, Magnesium, Clay and negative with Organic matter and Sand favoring the growth of species like G.ato, G.lal, J.uco, S.tte, M.asy, S.evu, P.eha, S.ima, T.yan, V.isa, V.umy, Z.ilo, T.aca and P.hau in station (1) (Figure 4, Table 2).

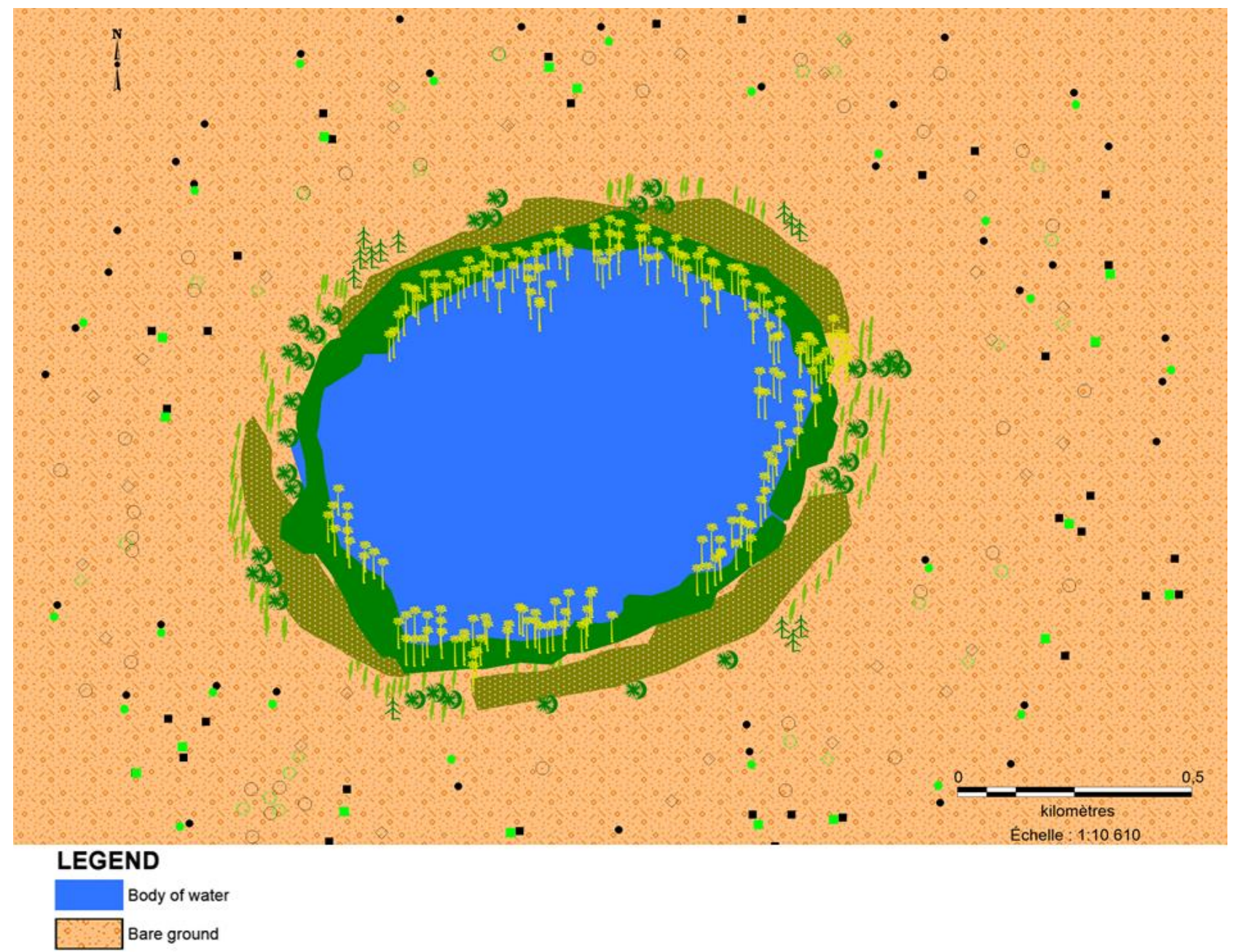

\section{Assembled species}

Phragmites australis (Cav.) Trin. ex Steud.

Tamarix canariensis Willd

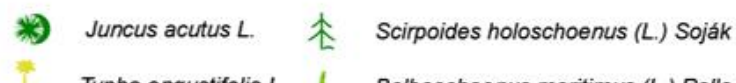
Typha angustifolia L. I Bolboschoenus maritimus (L.) Palla

\section{Sparse species}

$\because \because$ Marrubium vulgare $L$.

Atriplex halimus L. Chenopodium polyspermum $L$ Thymus vulgaris $L$ Malva sylvestris $L$.

Peganum harmala $L$. Papaver rhoeas $L$.

Globularia alypum L.

Plantago lanceolata $L$. Plantago major L

Andryala integrifolia $L$. Artemisia herba-alba Asso. Calendula arvensis (Vaill.) L. Galactites tomentosus Moench Matricaria chamomilla $L$. Pallenis spinosa (L.) Cass.

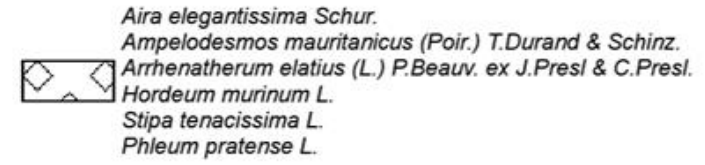

Vulpia myuros (L.) C.C.Gmel. Lysimachia monelli (L.) U.Manns \& Anderb.

Ranunculus arvensis $L$

Reseda alba $L$.

Ziziphus lotus (L.) Lam.

Scolymus hispanicus L Senecio vulgaris $L$

Silybum marianum (L.) Gaertn

Sonchus asper (L.) Hill Taraxacum campylodes G.E.Haglund

Borago officinalis $L$.

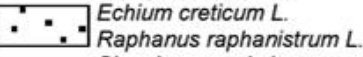

Sinapis arvensis $L$.

Figure 3. Mapping of distribution plant species in the Mekeiman Marsh, Souk Ahras, Northeast of Algeria 
Table 4. Mean and standard error $( \pm \mathrm{SE})$ values of the edaphic factors in the four-station, Mekeiman Marsh, Souk Ahras, Northeast of Algeria

\begin{tabular}{|c|c|c|c|c|c|}
\hline \multirow{2}{*}{ Soil variables } & \multicolumn{4}{|c|}{ Stations } & \multirow{2}{*}{ Mean $( \pm$ SE) } \\
\hline & S 1 & S 2 & S 3 & S 4 & \\
\hline Conductivity (mS/cm) & 2.43 & 1.85 & 4.68 & 3 & $2.99 \pm 1.22$ \\
\hline $\mathrm{pH}_{\mathrm{H} 2 \mathrm{O}}(1 / 2.5)$ & 8.1 & 7.825 & 7.92 & 7.9 & $7.94 \pm 0.12$ \\
\hline $\mathrm{C} / \mathrm{N}$ & 5.78 & 5.18 & 6.65 & 6.2 & $5.95 \pm 0.63$ \\
\hline Carbonates $(\%)$ & 11.19 & 9.16 & 8.05 & 11.52 & $9.98 \pm 1.66$ \\
\hline Active limestone (\%) & 5.53 & 2.89 & 3.18 & 8.04 & $4.91 \pm 2.40$ \\
\hline Organic matter (\%) & 0.87 & 1.16 & 1.01 & 0.71 & $0.94 \pm 0.19$ \\
\hline Total nitrogen $(\%)$ & 0.08 & 0.98 & 0.08 & 0.06 & $0.30 \pm 0.45$ \\
\hline Phosphorus (meq/100g) & 0.009 & 0.01 & 0.007 & 0.02 & $0.01 \pm 0.01$ \\
\hline Potassium $(\mathrm{meq} / 100 \mathrm{~g})$ & 0.6 & 0.4 & 0.6 & 0.5 & $0.53 \pm 0.10$ \\
\hline Magnesium (meq/100g) & 5.17 & 5.15 & 5.25 & 5.72 & $5.32 \pm 0.27$ \\
\hline Calcium (meq/100g) & 43.85 & 41.7 & 43.8 & 43.82 & $43.29 \pm 1.06$ \\
\hline Sodium (meg/100g) & 2.8 & 3.7 & 4.8 & 2.9 & $3.55 \pm 0.93$ \\
\hline Sand $(\%)$ & 45 & 43 & 39 & 37 & $41.00 \pm 3.65$ \\
\hline Silt (\%) & 30 & 26 & 24 & 30 & $27.50 \pm 3$ \\
\hline Clay (\%) & 25 & 31 & 37 & 33 & $31.50 \pm 5$ \\
\hline Texture & Sandy-Clay-Loam & Clayey & Clayey & Clayey & Clayey \\
\hline Structure & Massive & Massive & Massive & Massive & - \\
\hline Color & Yellowish-brown & Yellowish-brown & Yellowish-brown & Brown & - \\
\hline Slope (\%) & $10 \%$ & $5 \%$ & $5 \%$ & $10 \%$ & - \\
\hline
\end{tabular}

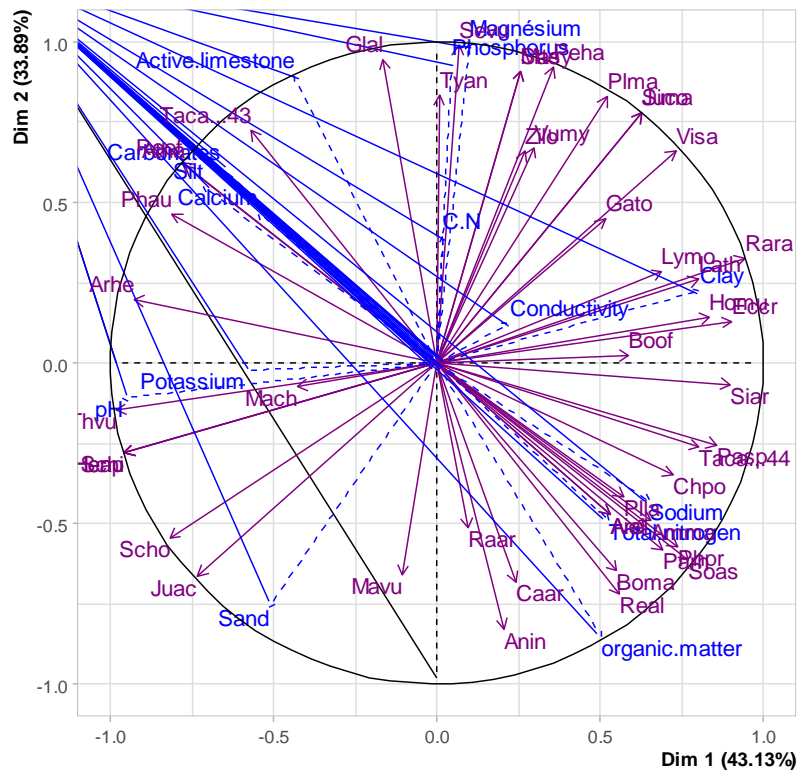

A

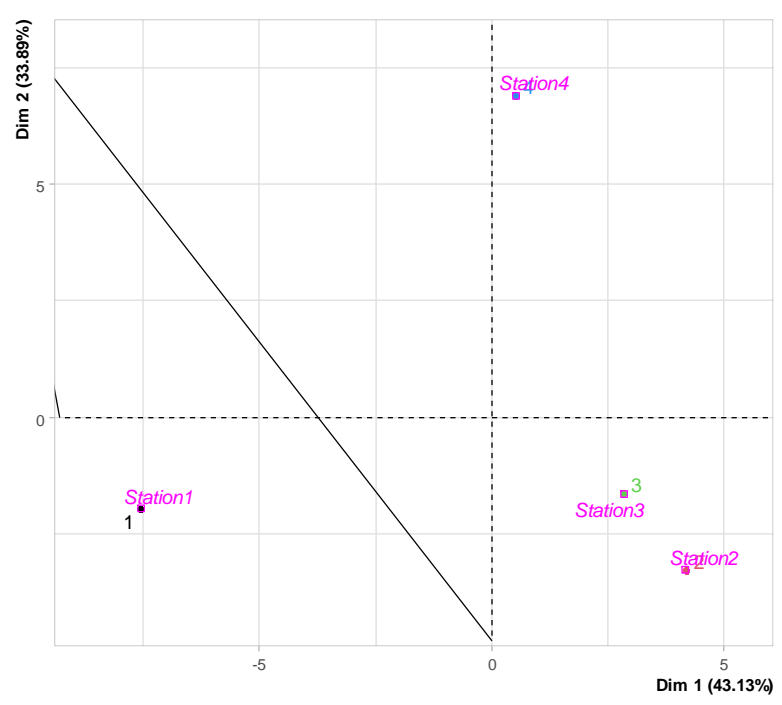

B

Figure 4. A. PCA plot of edaphic factors and plant species against their values for axes 1 and 2 in Mekeiman Marsh, Souk Ahras, North East of Algeria; B. Stations with respect to edaphic factors

The number of plant species reported in this study seems very interesting compared to that obtained by some authors in similar ecosystem in northeast of Algeria; including Korichi (2016) with 66 species, Yabrir et al. (2018) with 84 species and Bekai et al. (2019) with 106 species. This inventory reflects a diversity that is already well recorded for semi-arid regions of Algeria.

In Algeria, some studies (Benabadji et al. 2007; Djaballah and Chehma 2008; Kazi-Tani et al. 2010) highlighted the dominance of Compositae and Poaceae in semi-arid regions. Similar results were also reported by Korichi (2016); Rahmoune (2018) and Bekai et al. (2019) in northeast of Algeria. Our results are consistent with their results.

The dominance of hemicryptophytes and therophytes characterizes the arid and semi-arid regions (Miara et al. 2018). In this study, the high number of therophytes indicate some undergoing degradation of the local vegetation. These indicate the phenomenon of Therophytization in this wetland. The prevalence of 
hemicryptophytes can be explained by the degradation of the ecological conditions generally related to the climate and the anthropic action (Miara et al. 2018).

The other chronological types (chamaephytes, geophytes, microphanerophytes and nanophanerophytes) are moderate. Kadi-Hanifi (2003) reported that the number of chamaephytes and geophytes declined with the aridity and openness of the environment. This also indicates the adaptation of these species to the effect of the anthropic actions; they are perennial and annual plants with a short cycle and rapid development (Tecsult 2010).

The results of PCA analysis showed that there is a relatively high relationship between plant species and soil factors in Mekeiman Marsh wetland. The present study demonstrates that vegetation species increase with increase in sodium and phosphorus. The study findings were also close to those reported in the northern oak hardwood forest. northeastern America; drainage ditch banks, northern China and Oued Charef dam, northeast of Algeria (Bigelow and Canham 2002; Zhao and Jin 2011; Moualki and Boukrouma 2021). The role of Sodium in plant nutrition has generated numerous investigations which ultimately led to the conclusion that Sodium is the only monovalent cation that is essential for all higher plants (Plett and Moller 2010). Amorim and Batalha (2007) reported that Phosphorus was the main factor that defined plant communities in Brazil. One of the most important challenges for plant growth in the soils is the acquisition of available Phosphorus (Zhang et al. 2018). Sewerniak et al. (2017), also reported that soil Phosphorus content was one of the most common limiting elements of plants in ecosystems.

Márialigeti et al. (2016) demonstrated that soil Active limestone has a considerable impact on species diversity, which agrees with our findings. On the other hand according to, Fu et al. (2004) and Janssens et al. (1998) There was no relationship between species of vegetation and Active limestone. This disparity may be caused by the fact that habitats in different parts of the world are entirely different.

Peña-Claros et al. (2012) and Becknell and Powers (2014) showed a significant relationship between Magnesium and vegetation in rainforests and dry forests in Northwest Costa Rica. Our findings align with this funding. These results are similar to those of Ruocco et al. (2014), which report that plant species richness has a direct relationship with edaphic properties, i.e. high Magnesium concentration in the soil favoring some species in detriment of others.

Zielke et al. (2005) documented positive association of Clay content with plant species composition in a semiarid environment. The findings in this study were consistent with these results. Also, Adel et al. (2014) reported role of Clay, as a key factor in the distribution of plant species in a beech forest, north of Iran. Other researchers such as Mellado and Zamora (2015); Satir and Berberoglu (2016) reported that Clay is the most important factor for the distribution of the vegetation pattern.

Organic matter and $\mathrm{C} / \mathrm{N}$ were one of the important soil factors in the separation of the vegetation species in
Mekeiman Marsh. Organic matter has a high adsorption capability, which increases the soil's exchange capacity and therefore its fertility levels (Su et al. 2002; Zhenghu et al. 2004). Fu et al. (2004) noted that organic matter and $\mathrm{C} / \mathrm{N}$ content determined the distribution of plants in Beijing, China. Spencer et al. (2005) also emphasized the role of organic matter compounds in plant growth. Small and McCarthy (2005) reported that the ratio of $\mathrm{C} / \mathrm{N}$ was the main determinant factor of herbaceous plants. Other studies have also discussed the importance of Organic matter and $\mathrm{C} / \mathrm{N}$ in the distribution of plant species (Ladányi et al. 2016; Whitworth et al. 2016).

One of the significant soil variables of plant species in the study area was nitrogen. It is a crucial nutrient in many biological plant growth processes. In addition to being has a major influence on soil fauna and flora that can either make nutrients more available to plants in biological processes and growth causing short term deficiencies in plants. Many authors have reported that nitrogen is one of the most common limiting factors for plants in ecosystems (Wang et al. 2014) and closely related to plant diversity dynamics (Bobbink et al. 2010; Cong et al. 2014).

This investigation demonstrated that $\mathrm{pH}$, carbonate, potassium, calcium, silt and sand does not play an important role in the structure of vegetation in the study area. These results disagree with those reported in Tianshan Mountain Rang and Semi-arid grasslands, China (Sang 2009; Varin et al. 2009). A possible reason can lie in the fact that soil features appear to have different effects on the ecosystem structure and diversity of plant species.

To conclude, the results obtained in Mekeiman Marsh wetland showed an interesting richness of plant species (48 species, belonging to 21 families), which is mainly dominated by hemicryptophyte and therophyte taxa of low ecological and heritage value. Our results indicate the presence of the phenomenon of Therophytization in this wetland. The specific composition of plant species encountered in this wetland is often unstable; It can change year after year, or even in the same year. For this reason, the investigation of the dynamics of plant species of wetlands would be able to reveal very interesting adaptive strategies in the vegetation of wetlands. Results of this study showed that there is relationship between variation in soil factors and plant species in Mekeiman Marsh which is essential for vegetation restoration and management in wetlands ecosystems.

The structure and composition of plant species in this wetland must be understood further in order to determine the key reasons for the decline of vegetation. Finally, we insist on the necessity and the urgency to protect this natural ecosystem having a rich and original biodiversity.

\section{REFERENCES}

Adel MN, Pourbabaei H, Dey DC. 2014. Ecological species group. Environmental factors relationships in unharvested beech forests in the north of Iran. Ecol Eng 69: 1-7. DOI: 10.1016/j.ecoleng.2014.03.008.

Amorim PK, Batalha MA. 2007. Soil-vegetation relationships in hyperseasonal cerrado, seasonal cerrado, and wet grassland in Emas 
National Park (Central Brazil). Acta Oecol 32: 319-327. DOI: 10.1016/j.actao.2007.06.003.

Becknell JM, Powers JS. 2014. Stand age and soils as drivers of plant functional traits and aboveground biomass in secondary tropical dry forest. Can J For Res 44 (6): 604-613. DOI: 10.1139/cjfr-2013-0331.

Bekai F, Kadik L, Nedjimi B. 2019. Effects of deferring grazing on the floristic diversity of Stipa tenacissima Loefl. ex L. rangelands in central Algerian steppe. Afr J Ecol 57: 363-370. DOI: 10.1111/aje.2019.12614

Benabadji N, Benmansour D, Bouazza M. 2007. La flore des monts d'Ain Fezza dans l'ouest Algérien, biodiversité et dynamique. Sci Technol C Biotechnol 26: 47-59. [French]

Bigelow SW, Canham CD. 2002. Community organization of tree species along soil gradients in a north-eastern USA forest. J Ecol 90: 188200. DOI: 10.1046/j.ecol.2002. 0022-0477.2001.00655.x.

Bobbink R, Hicks K, Galloway J, Spranger T, Alkemade R, Ashmore M. 2010. Global assessment of nitrogen deposition effects on terrestrial plant diversity: A synthesis. Ecol Appl 20 (1): 30-59. DOI: 10.1890/j. Ecol Appl.2010.08-1140.1

Braun-Blanquet J. 1932. Plant Sociology. McGraw-Hill, New York.

Braun-Blanquet J.1964. Pflanzensociologie: Grundzuge der VegetationSkunde. 3te aufl. Springer-Verlag, Viena.

Chang CC, Turner BL. 2019. Ecological succession in a changing world. $J$ Ecol 107: 503-509. DOI: 10.1111/j.ecol.2019.1365-2745.13132

Chen JL, Fang X, Gu X, Li LD, Liu ZD, Wang LF, Zhang SJ. 2019 Composition structure and floristic characteristics of two forest communities in Central-Subtropical China. Sci Silvae Sin 55 (2): 159172.

Chenchouni H. 2007. Ecological Diagnosis of a Proposed Ramsar Site: Chott de Djendli (Batna-Algeria). [Thesis]. University El Hadj Lakhdar, Batna, Algeria.

Cong WF, Ruijven JV, Mommer L, De Deyn GB, Berendse F, Hoffland E. 2014. Plant species richness promotes soil carbon and nitrogen stocks in grasslands without legumes. J Ecol 102 (5): 1163-1170. DOI: 10.1111/j.ecol.2014.1365-2745.12280.

Couplan F, Styner E. 2013. Edible and Toxic Wild Plants. Guide Delachaux and Niestle, Parais.

Demenois J, Rey F, Ibanez T, Stokes A, Carriconde F. 2018. Linkages between root traits, soil fungi and aggregate stability in tropical plan communities along a successional vegetation gradient. Plant Soil 424 (1-2): 319-334. DOI: 10.1007/j.plant soil .2018.s11104-017-3529-x.

Djaballah F, Chehma A. 2008. Effet de deux Méthodes d'aménagement (mise en défens et plantation) sur les Caractéristiques Floristiques et Nutritives des Parcours Steppiques de la Région de Djelfa. [Thesis] University of Ouargla, Algeria. [French]

Eghdami H, Azhdari G, Lebailly P, Azadi H. 2019. Impact of land-use changes on soil and vegetation characteristics in Fereydan, Iran Agriculture 9 (3): 58. DOI: 10.3390/j.agriculture.2019.9030058.

Fu BJ, Liu SL, Ma KM, Zhu YG. 2004. Relationship between soil characteristics, topography and plant diversity in a heterogeneous deciduous broad-leaved forest near Beijing, China. Plant Soil 261: 47 54. DOI: 10.1023/B:PLSO.0000035567.97093.48

Gillet F. 2000. Integrated Synusial Phytosociology, Methodological Guide, Document 1. Institute of Botany, University of Neuchâtel, Switzerland

Gu X, Fang X, Xiang WH, Zeng YL, Zhang SJ, Lei PF, Peng C, Kuzyakov Y. 2019. Vegetation restoration stimulates soil carbon sequestration and stabilization in a subtropical area of southern China. Catena 181: 104098. DOI: 10.1016/j.catena.2019.104098.

Guesmi B. 2004. Degradation of Water Quality in The Medjerda Wadi (Souk Ahras). [Thesis]. University of Batna, Algeria.

Jager NRD, Rohweder JJ, Yao Y, Hoy EE. 2015. The Upper Mississippi River floodscape: spatial patterns of flood inundation and associated plant community distributions. Appl Veg Sci 19: 164-172. DOI: 10.1111/avsc.2015.12189.

Janssens F, Peeters A, Tallowin JRB, Bakker JP, Bekker RM, Fillat F, Oomes MJM. 1988. Plant Soil 202: 69-78. DOI: 10.1023/j.plantsoil.1988.A:1004389614865.

Jerôme C. 2011. Wild Plants Guide to Recognize Everything in Nature. Reader's Digest Selection, France.

Kadi-Hanifi H. 2003. Diversité biologique et phytogéographique des formations à Stipa tenacissima L. de 1'Algérie. Science et changements planétaires Sécheresse 14 (3): 169-179. [French]

Kazi-Tani C, Bourgeois TL, Munoz F. 2010. Contribution à l'étude des communautés d'adventices des cultures du secteur phytogéographique Oranais (Nord-Ouest Algérien): aspects botanique, agronomique et phyto-écologique. Association Française de Protection des Plantes. AFPP - 21e Conférence du COLUMA - Journées internationales sur la lutte contre les mauvaises herbes, Dec 2010, Dijon, France. [French]

Korichi A. 2016. Etude Floristique et Ethnobotanique de Chouchet Tobdji (forêt de Sénalba Chergui) -Région de Djelfa. [Thesis]. University Djelfa, Algeria. [French]

Ladányi E, Persici V, Fiveash A, Tillmann B, Reyna L. 2016. Is a typical rhythm a risk factor for developmental speech and language disorders? Adv Rev 11 (5): 1-32. DOI: 10.1002/j. adv rev 2016.wcs.1528.

Long G. 1974. Phytoecological Diagnosis and Spatial Planning. Volume I. General Principles and Methods. Masson \& Cie Edition.

Maren IE, Sharma LN. 2018. Managing biodiversity: impacts of legal protection in mountain forests of the Himalayas. Forests 9: 476. DOI: $10.3390 /$ j. Forests.2018. f 9080476

Márialigeti S, Tinya F, Bidló A, Ódor P. 2016. Environmental drivers of the composition and diversity of the herb layer in mixed temperate forests in Hungary. Plant Ecol 217 (5): 549-563. DOI: 10.1007/j.plant ecol.2016..s11258-016-0599-4.

Meddour R. 1994. Contribution to The Phytosociological Study of The Central-Eastern Portion of The Chrea National Park. Synthetic Interpretation of The Stages and Series of Vegetation of The Atas Blideen. [Thesis]. INA, El Harrach, Algeria.

Mellado A, Zamora R. 2015. Spatial heterogeneity of a parasitic plant drives the seed-dispersal pattern of a zoochorous plant community in a generalist dispersal system. Funct Ecol 30 (3): 459-467. DOI: 10.1111/j.funct ecolo.2015.1365-2435.12524.

Miara MD, Ait Hammou M, Dahmani W, Negadi M, Djellaoui et A. 2018. Nouvelles données sur la flore endémique du sous-secteur de l'Atlas tellien Oranais "O3" (Algérie occidentale). Acta Bot Malacit 43: 63-69. DOI: 10.24310/j.abm.2018.v43i0.4453.

Moualki N, Boukrouma N. 2021. The influence of environmental factors on the distribution and composition of plant species in Oued Charef dam, northeast of Algeria. Biodiversitas 22 (1): 346-353. DOI: 10.13057j./biodiv.2021.d220142.

O'Connell JL, Johnson LA, Smith LM, McMurry ST, Haukos DA. 2012. Influence of land-use and conservation programs on wetland plant communities of the semiarid United States Great Plains. Biol Conserv 146 (1): 108-115. DOI: 10.1016/j.biocon.2011.11.030.

Ozenda P. 1986. Ecological Mapping and Its Applications. Masson. Paris.

Peña-Claros M, Poorter L, Alarcón A, Blate G, Choque U, Fredericksen TS, Justiniano MJ, Leano C, Licona JC, Pariona W, Putz FE, Quevedo L, Toledo M. 2012. Soil effects on forest structure and diversity in a moist and a dry tropical forest. Biotropica 44 (3): 276283. DOI: 10.1111/j.biot.2012.1744-7429.2011.00813.x

Plett DC, Møller IS. 2010. $\mathrm{Na}^{+}$transport in glycophytic plants: what we know and would like to know. Plant Cell Environ 33: 612-626. DOI: 10.1111/j.plant cell environn.2010.1365-3040.2009.02086.x.

Quezel P, Santa S. 1962. The New Flora of Algeria and The Southern Desert Regions. Volume II, Edition: CNRS, Paris

R Development Core Team. 2016. R: A language and environment for statistical computing. R Foundation for Statistical Computing, Vienna, Austria

Rahmoune A. 2018. Ecologie et Analyse Floristique de la Végétation et de la Flore de la Forêt de Sahary Guebli (Réserve de Chasse) Wilaya de Djelfa. [Thesis]. University of Batna, Algeria. [French]

Raunkiær C, Gilbert-Carter H, Fausbøll A, Tansley AG. 1934. The Life Forms of Plants and Statistical Plant, Geography. Clarendon Press, Oxford.

Ruocco M, Bertoni D, Sarti G, Ciccarelli D. 2014. Mediterranean coastal dune systems: Which abiotic factors have the most influence on plant communities? Estuar Coast Shelf Sci 149: 213-222. DOI: 10.1016/j.ecss.2014.08.019.

Sang W. 2009. Plant diversity patterns and their relationships with soil and climatic factors along an altitudinal gradient in the middle Tianshan Mountain area, Xinjiang, China. Ecol Res 24 (2): 303-314. DOI: $10.1007 /$ j.ecol res.2009.s11284-008-0507-z.

Satir O, Berberoglu S. 2016. Crop yield prediction under soil salinity using satellite-derived vegetation indices. Field Crops Res 192: 134143. DOI: $10.1016 /$ j.fcr.2016.04.028.

Sewerniak P, Jankowski M, Dąbrowski M. 2017. Effect of topography and deforestation on regular variation of soils on inland dunes in the Toruń Basin (N Poland). Catena 149: 318-330. DOI: 10.1016/j.catena.2016.10.008. 
Silva KJP, Souza AF. 2018. Common species distribution and environmental determinants in South American coastal plains. Ecosphere 9 (6): e02224. DOI: 10.1002/j.ecosphere.2018.ecs2.2224.

Small CJ, McCarthy BC. 2005. Relationship of understory diversity to soil nitrogen, topographic variation and stand age in an eastern Oak forest USA. For Ecol Manag 217 (2-3): 229-243. DOI: 10.1016/j.foreco.2005.06.004.

Soltner D. 2005. The Basis of Plant Production. The Soil and Its Improvement, Agricultural Science and Technique Collection, 24 ed, Paris.

Spencer DF, Ksandera GG, Whitehand LC. 2005. Spatial and temporal variation in RGR and leaf quality of a clonal riparian plant: Arundo donax. Aquat Bot 81 (1): 27-36. DOI: 10.1016/j.aquabot.2004.11.001.

Su YZ, Zhao HL, Zhang TH. 2002. Influencing mechanism of several shrubs and subshrubs on soil fertility in Keerqin sandy land. J Appl Ecol 13 (7): 802-806.

Tecsult. 2010. Study of the wetland cadastre: Report 3: Environmental characterization (Component 3): Chott Timerganine, Ministry of Regional Planning, Environment and Tourism. Department of the Conservation of Biodiversity, Natural Environment, Sites and Landscapes, Algeria.

Touarfia M. 2012. Structure and Dynamics of Vegetation in The Timerganine Garaet (Oum El-BOUAGHI, Sudde du Constantinois) [Thesis]. Mohamed Cherif Messaadia University Center, Souk Ahras, Algeria.

Varin S, Lemauviel-Lavenant S, Cliquet JB, Diquélou S, MichaelsonYeates TPT. 2009. Functional plasticity of Trifolium repens L. In response to sulphur and nitrogen availability. Plant Soil 317 (1): 189200. DOI: 10.1007/j.plant soil .2009.s11104-008-9800-4.

Violle C, Bonis A, Plantegenest M, Cudennec C, Damgaard C, Marion B, Le Coeur D, Bouzille JB. 2011. Plant functional traits capture species richness variations along a flooding gradient. Oikos 120 (3): 389-398. DOI: 10.1111/j.oikos.2011.1600-0706.2010.18525.x.

Wang D, Zhang B, Zhu LL, Yang YS, Li MM. 2018. Soil and vegetation development along a 10 -year restoration chronosequence in tailing dams in the Xiaoqinling gold region of Central China. Catena 167: 250-256. DOI: 10.1016/j.catena.2018.05.007.

Wang Q, Jacob DJ, Spackman JR, Perring AE, Schwarz JP, Moteki N, Barrett SRH. 2014. Global budget and radiative forcing of black carbon aerosol: Constraints from pole-to-pole (HIPPO) observations across the Pacific. J Geophys Res 1119 (1): 95-206. DOI: 10/j.geo res.2014.1002/2013JD020824.

Whitworth A, Villacampa J, Brown A, Huarcaya RP, Downie R, MacLeod R. 2016. Past human disturbance effects upon biodiversity are greatest in the canopy; a case study on rainforest butterflies. PLoS One 11 (3): e0150520. DOI: 10.1371/journal.pone.0150520.

Williams LD, Ahn CW. 2015. Plant community development as affected by initial planting richness in created mesocosm wetlands. Ecol Eng 75: 33-40. DOI:10.1016/j.ecoleng.2014.11.030.

Wu GL, Ren GH, Wang D, Shi ZH, Warrington D. 2013. Above- and below-ground response to soil water change in an alpine wetland ecosystem on the Qinghai Tibetan plateau, China. J Hydrol 476 (4): 120-127. DOI: 10.1016/j.jhydrol.2012.10.031.

Yabrir B, Touati M, Adli B, Bezini E, Ghafoul M, Khalifa S, Guit B. 2018. Therapeutic use of spontaneous medicinal flora from an extreme environment (dune cordon) in Djelfa region, Algeria. J Pharm Pharmacogn Res 6 (5): 358-373.

Zhang XN, Yang XD, Li Y, He XM, Lv GH, Yang JJ. 2018. Influence of edaphic factors on plant distribution and diversity in the arid area of Xinjiang, Northwest China. Arid Land Res Manag 32 (1): 38-56. DOI: 10.1080/ j.arid land res manag.2018.15324982.2017.1376004.

Zhang YH, Xu XL, Li ZW, Liu MX, Xu CH, Zhang RF, Luo W. 2019. Effects of vegetation restoration on soil quality in degraded karst landscapes of Southwest China. Sci Total Environ 650: 2657-2665. DOI: 10.1016/j.scitotenv.2018.09.372.

Zhao F, Jin H L. 2011. Study on characteristics of groundwater and its impact on Populus euphratica along the banks of Aqikesu River. J Arid Land Res Environ 25: 156-60.

Zhenghu D, Honglang X, Xinrong L, Zhibao D, Gang W. 2004. Evolution of soil properties on stabilized sands in the Tengger Desert, China. Geomorphology $59 \quad(1-4): \quad 237-246 . \quad$ DOI: 10.1016/j.geomorph.2003.07.019.

Zielke M, Solheim B, Spjelkavik S, Olsen RA. 2005. Nitrogen fixation in the high Arctic: Role of vegetation and environmental conditions. Arct Antarct Alp Res 37 (3): 372-378. DOI: 10./j.antarct alp res.2005.2307/4095899. 